to linger on, such as "amitosis" as a mode of cell replacement in certain organs. For instance, as far as the gall bladder is concerned, genuine mitotic activity of the epithelium of this organ has been demonstrated. I would also like to see the nervous influences affecting ovarian processes related to the complex system of transmission"CNS-hypothalamus-anterior pituitary"--rather than to autonomic ovarian nerves. With reference to some of the illustrations, an oversight has occurred in Fig. 451, where $a$ and $b$ should be reversed; and in Fig. 35, it seems, concerning the magnification. In the borrowed diagram of the oesophageal wall (Fig. 412) the "Ringmuskulatur" is drawn as if its fibres are running radially. This may not matter for the initiated but can be confusing for students.

It is to the great credit of the author and his literary skill that, in spite of the incorporation of much new material, the size of the volume has remained practically unaltered. This is a text which is stimulating, sometimes challenging, not only for the undergraduate but equally so for the postgraduate or even the postdoctorate.

This particular edition is fittingly dedicated to Frau Professor Berta Scharrer of New York. F. JACOBY

\section{ASPECTS OF DIFFERENTIATION}

\section{Cell Differentiation}

Edited by A. V. S. de Reuck and Julie Knight. Pp. 257. (Churchill: London, 1968.) $60 s$.

How do cells differ from one another? This volume presents the contributions by many eminent researchers towards the understanding of a problem that has long been with us. The papers were delivered at a symposium held under the auspices of the Ciba Foundation in London last year.

There are fourteen papers and three general discussions on various aspects of differentiation. The topics range from the properties of natural and artificial membranes (by M. D. Rosenberg) to cellular and tissue interactions (by E. J. Ambrose, T. Yamada et al.) and from gene expression during early development (by J. Brachet, J. B. Gurdon and E. Bell) to gene regulation and masking in differentiated cells (by G. P. Georgie and J. Paul). Extensive discussion follows each paper and its informal nature has been retained by careful editing so as to makc both easy and informative reading. None of the authors claims to have said the last word on his subject and in some cases what is said is admitted to be speculation. There is, however, much of value in this book.

P. W. BARLOW

\section{NUTRITION CONGRESS}

\section{Proceedings of the Seventh International Congress of} Nutrition, Hamburg, 1966

Vol. 1 : Nutrition and Health. Pp. 369. Vol. 2: Regulation of Hunger and Satiety. Pp. 272. Vol. 3: Nutrition under Various Geographic and Climatic Conditions. Pp. 371. Vol. 4: Problems of World Nutrition. Pp. 1091. Vol. 5: Physiology and Biochemistry of Food Components. Pp. 880. (Vieweg: Braunschweig; Pergamon: Oxford, London and New York, 1967.) $£ 40$ the set of five volumes.

A COMPILATION such as this presents the reviewer with a virtually impossible task. It is possible to do no more than hint at the many interesting and important papers which were presented at the congress in the summer of 1966. Each volume has an author index and the table of contents of the entire work is repeated at the end of each volume. The assignment of papers between volumes 3 and 4 is in some cases rather arbitrary and it is a little unfortunate that an author index covering the five volumes is not included.

The number of papers presented gives some indication of the growth of nutritional science and the printed proceedings occupy more than three times as many pages as the report of the previous congress.

Within each volume the contributions are grouped into plenary sessions, symposia and round table discussions. The papers in the plenary sessions are given in full, those of the symposia and discussions usually in abbreviated form, occasionally as very short abstracts. The reports of the discussions are confined to the introductory papers and the chairman's comments.

Time alone can provide the answer to the question as to which of the many contributions was the more significant. We can only select a few which seem of special interest.

In volume 1 the plenary lectures by Scrimshaw on "Nutrition and Infection" and Pokrovsky on "The Problem of the Influence of Nutrition on the Health of People", the symposium on the long-term effects of protein-calorie malnutrition and the discussion on nutrition and mental development are of particular interest.

In the second volume probably the most pressing nutritional problem in the developed countries is considered in the symposium on the regulation of fat metabolism and the problems of obesity. The discussion on food habits, patterns and taboos emphasizes some often neglected aspects of human nutritional problems.

Volume 3 covers the socio-economic aspects of the problems connected with the world's food supplies and the symposium on vegetable sources of protein for young children may point to one way of alleviating proteincalorie malnutrition.

The nutritional problems of the world are further discussed in the fourth volume, and the first plenary session in which some evolutionary aspects of human nutrition are presented is of considerable interest. In the plenary session which considered world nutrition in the future, Darby, Mašek, Wilbrandt, Bengoa, Bigwood and Fischnich and his colleagues point to the problems which each, in his own way, sees as awaiting the researchers.

The final volume contains the more "conventional" nutritional papers in sections covering nutrition in general, digestion and absorption, amino-acids, proteins, plant proteins in nutrition, lipids, carbohydrates, vitamins, minerals, trace elements, micro-nutrients of uncertain structure and the pharmacological and toxicological effects of food components. Each section contains abstracts which will interest all concerned with nutrition.

The wealth of information contained in these five volumes makes it inevitable, however, that each and every reader will find papers which interest him personally and which seem to him of greater importance than any mentioned in the review.

The proceedings thus emphasize the very wide range of disciplines contributing to nutritional studies, and the papers range from historical and evolutionary studies of human nutrition to work on the role of nutrients at the cellular level. The overriding problem, however, which runs through the entire proceedings, is that of malnutrition, particularly protein-calorie malnutrition in many, if not all, of the developing countries of the world.

Many papers show that the fundamental aspects of this problem are often sociological and economic in nature, and it is to be hoped that these volumes will find a place in the libraries of sociological and economic departments in addition to those of the scientific disciplines more usually associated with nutrition.

For a reference work of this sort the choice of binding seems unsuitable and, while we sympathize with the editor in the magnitude of such an undertaking, we feel that more rigorous editing could have produced an even more useful and less expensive report of the congress.

\section{A. T. Southgate}

E. M. WIDDowson 